Vol 11, Issue 9, 2018

online - 2455-3891

Print - 0974-2441

$\underline{\text { Research Article }}$

\title{
THE WOUND HEALING PROPERTY OF THYME OLEORESIN FROM THYMUS VULGARIS L. ON HACAT KERATINOCYTES
}

\author{
ROY ANITHA*, V .S .SUBEEKSHA, THANGAVELU LAKSHMI
}

Department of Pharmacology, Saveetha Dental College, Saveetha Institute of Medical and Technical Sciences, Saveetha University, Chennai, Tamil Nadu, India. Email: anitharoy2015@gmail.com

Received: 30 April 2018, Revised and Accepted: 18 May 2018

\begin{abstract}
Objective: The objective of the present study was to evaluate the wound healing property of thyme oleoresin using HaCaT keratinocytes.

Methods: The effect of thyme oleoresin on cell migratory activity of HaCaT keratinocytes was investigated and analyzed using scratch assay. The HaCaT cell line was obtained from NCCS Pune and maintained in Dulbecco's Modified Eagle's Media. The keratinocyte cells (HaCaT) were trypsinized for $30 \mathrm{~s}$ and passaged to T25 flasks in complete aseptic environment. The effect of thyme oleoresin on wound closure was determined using a 12-well plate. Dulbecco's Modified Eagle's medium with dimethyl sulfoxide was used as control. The effect of thyme oleoresin on wound closure was determined microscopically at 20x magnification using Nikon microscope. The experiment was performed in triplicate. The wound area was photographed and analyzed.
\end{abstract}

Results: Thyme oleoresin at $25 \mu \mathrm{g} / \mathrm{ml}$ and $50 \mu \mathrm{g} / \mathrm{ml}$ has significantly promoted the migration of HaCaT cells, thereby leading to wound closure.

Conclusion: The study has proved the wound healing property of thyme oleoresin, and hence, it may be used for wound healing purpose in a natural way.

Keywords: Thyme oleoresin, HaCaT cell line, Keratinocytes, Wound healing, Scratch assay.

(C) 2018 The Authors. Published by Innovare Academic Sciences Pvt Ltd. This is an open access article under the CC BY license (http://creativecommons. org/licenses/by/4. 0/) DOI: http://dx.doi.org/10.22159/ajpcr.2018.v11i9.26987

\section{INTRODUCTION}

Thymus vulgaris L. is an aromatic medicinal plant. It is used in folk medicine, phytopharmaceutical preparations, and also for food preservation [1]. In folk medicine, some Thymus spp. are used for their antihelminthic, expectorant, antiseptic, antispasmodic, antimicrobial, antifungal, antioxidative, antivirotic, carminative, sedative, and diaphoretic effects $[2,3]$. In this study, scratch assay was used to explore the wound healing property of thyme oleoresin. Oleoresins are rich in antioxidants and are normally composed of essential oils and resins from herbs [4]. The essential oil of thyme contains $\alpha$-pinene, 3-carene, p-Cymene,1-8 cineole, limonene, borneol, $\alpha$-terpineol, thymol, carvacrol, $\beta$ caryophyllene, geraniol, linalool, gamma-terpineol, carvacrol, thymol, and transthujan-4-ol/terpinen-4-ol [5-7]. Thymol and carvacrol are known for its antioxidative, antimicrobial, antitussive, expectorant, antispasmodic, and antibacterial effects [8-12]. The constituents reported in thyme oleoresins are thymol, p-cymene, borneol, terpinol, carvacrol, and linalool $[13,14]$.

The conventional method to screen the wound healing property of plant products is invasive procedures in animal models. Many in vitro assays can be used to screen many plant products having antioxidant, cell mobilization, and angiogenic properties essential for wound healing [15]. Moreover, plants are explored for their various pharmacological activities such as antihyperglycemic activity, anticancer, and antimicrobial activities [16-18]. Here, in this study, the effect of thyme oleoresin on cell migratory activity of HaCaT keratinocytes was investigated and analyzed using scratch assay.

\section{METHODS}

\section{Cell culture}

HaCaT cell line was obtained from NCCS Pune and maintained in Dulbecco's Modified Eagle's Media (DMEM) supplemented with 10\% fetal bovine serum (FBS) and grown to confluency at $37^{\circ} \mathrm{C}$ in $5 \% \mathrm{CO}_{2}$ in a $\mathrm{CO}_{2}$ incubator. The keratinocyte cells (HaCaT) were trypsinized for $30 \mathrm{~s}$ and passaged to T25 flasks in the complete aseptic environment.

\section{Cell migration assay}

The effect of thyme oleoresin on wound closure was determined using a 12 -well plate. Exponentially growing HaCaT cells in DMEM (1\% FBS) were trypsinized and then seeded at a density of 200,000 cells into a 12 -well plate and cultured overnight to allow adhering and reaching a $90 \%$ confluence. The scratch wound was made by a sterile $1 \mathrm{~mL}$ pipette tip through a pre-marked line. The cell monolayer was subsequently rinsed 3 times with PBS followed by incubation with indicated concentrations of thyme extract $(25 \mu \mathrm{g} / \mathrm{mL}$ and $50 \mu \mathrm{g} /$ $\mathrm{mL}$ ) and epidermal growth factor (EGF) (4 ng/ml) for $30 \mathrm{~min}$ and incubated at $37^{\circ} \mathrm{C}$ for $24 \mathrm{~h}$ in a $\mathrm{CO}_{2}$ incubator. DMEM medium with dimethyl sulfoxide (DMSO) was used as control. The effect of thyme extract on wound closure was determined microscopically (20x magnification, Nikon microscope). The experiment was performed in triplicate. The wound area was photographed and analyzed [19].

\section{RESULTS}

The effect of thyme extract on cell migratory activity of HaCaT keratinocytes was investigated and analyzed using scratch assay. Thyme extract at $25 \mu \mathrm{g} / \mathrm{ml}$ and $50 \mu \mathrm{g} / \mathrm{ml}$ has significantly promoted the migration of HaCaT cells, thereby leading to wound closure (Fig. 1) compared to control, DMSO, and EGF.

\section{DISCUSSION}

In the present study, the effect of thyme oleoresin on the migration of HaCaT cells was studied and was observed that the HaCaT cells mobilized toward the artificially created cell injury under the influence of thyme. 

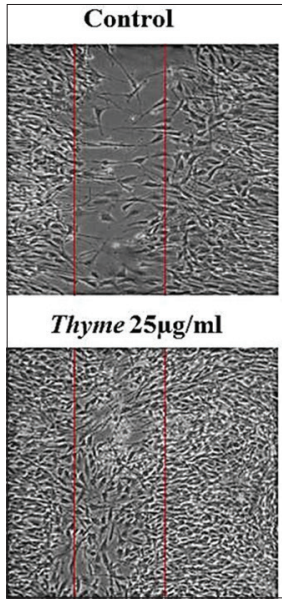

DMSO
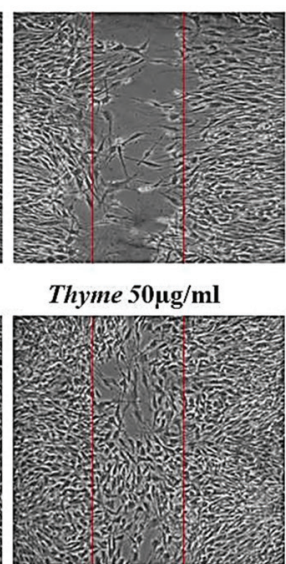

Thyme $50 \mu \mathrm{g} / \mathrm{ml}$
$0.2 \%$ FBS

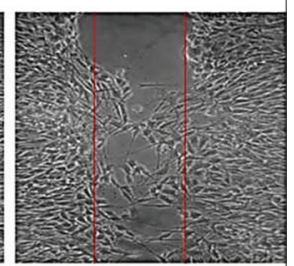

EGF 4ng/ml

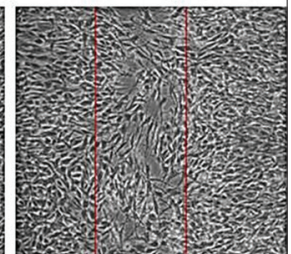

Fig. 1: Photographs showing the cell migratory activity of HaCaT keratinocytes of thyme oleoresin

It was reported that the wound healing and antioxidant properties exist together and the wound healing process can be aided by the presence of antioxidants [20]. Thyme oleoresin is known for its antioxidant activity. Thyme oleoresin is distilled from the aerial parts. The aerial part of the plants is reported to have major components such as p-cymene, $\gamma$-terpinene, and thymol [21]. Tissue injury initiates a cascade of events such as inflammation, new tissue formation, and remodeling. The healing process is modulated by the associated molecular signals through cytokines and growth factors [22]. Rapid migration and proliferation of keratinocytes are required for the wound healing process [23]. Re-epithelialization of the epithelium occurs by proliferation and migration of epithelial cells atop of the wound bed providing cover for the new tissue [24]. Hence, the effect of thyme oleoresin on cell migratory activity of HaCaT keratinocytes was investigated and analyzed using scratch assay. The scratch wound healing assay enables a large number of substances to be tested and analyzed which is relatively simple to carry out [25]. Animal models are also used extensively for the evaluation of wound healing property of plant extracts but which always have invasive procedures [26].

Tribals and folklore in many countries use a number of plants for the treatment of wounds and burns as they have real potential to heal wounds. Multiple mechanisms are involved behind this healing and regeneration of the lost tissue [27]. Several plant extracts and natural compounds have been reported to have anti-inflammatory effects in activated keratinocytes and in animal models [26,28-30]. Aloe vera is one such plant reported to have wound healing property. The possible mechanisms in wound healing may be its ability to keep the wound moist, enhancing epithelial cell migration, rapid maturation of collagen and reducing the inflammation, increasing the collagen synthesis, increase in synthesis of hyaluronic acid and dermatan sulfate in the granulation tissue of the healing wound, and improving the oxygenation by increased blood supply [31-34]. Thyme extract at different concentrations used in the study has significantly promoted the migration of HaCaT cells, thereby showing its ability in wound healing.

\section{CONCLUSION}

Thyme oleoresin has significantly promoted the migration of HaCaT cells, thereby leading to wound closure. Hence, it may be used in formulations for the management of wound closure in a natural way.

\section{ACKNOWLEDGEMENT}

The authors thank Synthite Industries Pvt. Ltd., Kerala, for providing the extract for the study and the management of Saveetha Dental College for all the support to carry out this short term project.

\section{AUTHOR'S CONTRIBUTION}

All the authors have equally contributed towards the compilation of this research article.

\section{CONFLICTS OF INTEREST}

The authors declare that there is no conflict of interest in publishing this paper

\section{REFERENCES}

1. Fachini-Queiroz FC, Kummer R, Estevão-Silva CF, Bastos RL, Grespan R, de Souza Silva-Comar FM, et al. Effects of thymol and carvacrol, constituents of Thymus vulgaris L. essential oil, on the inflammatory response. Evid Based Complement Altern Med 2012;2012:657026.

2. Soliman KM, Badeaa RI. Effect of oil extracted from some medicinal plants on different mycotoxigenic fungi. Food Chem Toxicol 2002;40:1669-75.

3. Jain N, Sharma M. Screening of Thymus vulgaris essential oil against fungi causing dermatophytosis in human beings. Int J Pharm Pharm Sci, 2017; 9:236-9

4. Ergun AR, Baysal T. The antimicrobial effects of thyme, garlic and basil oleoresins against Bacillus coagulans in tomato sauce. J Food Biochem 2017;41:e12296.

5. Nowak A, Kalemba D, Piotrowska M, Czyżowska A. Effects of thyme (Thymus vulgaris L.) and rosemary (Rosmarinus officinalis L.) essential oils on growth of Brochothrix thermosphacta. Afr J Microbiol Res 2013;7:3396-404.

6. Rota MC, Herrera A, Martínez RM, Sotomayor JA, Jordán MJ. Antimicrobial activity and chemical composition of Thymus vulgaris, Thymus zygis and Thymus hyemalis essential oils. Food Control 2008; 19:681-7.

7. Thompson JD, Chalchat JC, Michet A, Linhart YB, Ehlers B. Qualitative and quantitative variation in monoterpene co-occurrence and composition in the essential oil of Thymus vulgaris chemotypes. $\mathrm{J}$ Chem Ecol 2003;29:859-80.

8. Hoferl M, Buchbauer G, Jirovetz L, Schmidt E, Stoyanova A, Denkova $\mathrm{Z}$, et al. Correlation of antimicrobial activities of various essential oils and their main aromatic volatile constituents. J Essent Oil Res 2009;21:459-63.

9. Youdim KA, Dorman HJ, Deans SG. The antioxidant effectiveness of thyme oil, $\alpha$-tocopherol and ascorbyl palmitate on evening primrose oil oxidation. J Essent Oil Res 1999;11:643-8

10. Barnes J, Anderson LA, Philipson JD. Herbal Medicines. $3^{\text {rd }}$ ed. London, UK: Pharmaceutical Press; 2007.

11. Dorman HJ, Deans SG. Antimicrobial agents from plants: Antibacterial activity of plant volatile oils. J Appl Microbiol 2000;88:308-16.

12. ESCOP. ESCOP Monographs: The Scientific Foundation for Herbal Medicinal Products. $2^{\text {nd }}$ ed. Exeter, UK: The European Scientific Cooperative on Phytotherapy in Collaboration with Georg Thieme; 2007.

13. Bagamboula CF, Uyttendaele M, Debevere J. Inhibitory effect of thyme and basil essential oils, carvacrol, thymol, estragol, linalool and p-cymene towards Shigella sonnei and S. flexneri. Food Microbiol 2004;21:33-42.

14. Lucchesi ME, Chemat F, Smadja J. Solvent free microwave extraction of essential oil from aromatic herbs: Comparison with conventional hydrodistillation short communication. J Chromatogr A 2004;1043:323-7.

15. Talekar YP, Apte KG, Paygude SV, Tondare PR, Parab PB. Studies on wound healing potential of polyherbal formulation using in vitro and in vivo assays. J Ayurveda Integr Med 2017;8:73e81.

16. Sitorus P, Rosidah R, Satria D. Hypoglycemic activity of ethanolic extract of Saurauia vulcani korth Leaves. Asian J Pharm Clin Res 2018;11:35-6.

17. Ashwini S, Ezhilarasan D, Anitha R. Cytotoxic effect of Caralluma fimbriata against human colon cancer cells. Pharmacogn J 2017;9:98-101.

18. Ferdioz J, Roy A. Antibacterial activity of aqueous alcoholic extract of Abutilon indicum aerial parts against Enterococcus faecalis - An in vitro study. Asian J Pharm Clin Res 2017;10:80-8.

19. Chen HH, Zhou HJ, Fang X. Inhibition of human cancer cell line growth and human umbilical vein endothelial cell angiogenesis by artemisinin derivatives in vitro. Pharmacol Res 2003;48:231-6.

20. Suntar I, Kupeli AE, Nahar L, Satyajit D, Sarker SD. Wound healing and antioxidant properties: Do they coexist in plants. Fr Rad Antioxid 2012;2:1e7. 
21. Boruga O, Jianu C, Misca C, Golet I, Gruia A, Horhat F. Thymus vulgaris essential oil: Chemical composition and antimicrobial activity. J Med Life 2014;7:56-60.

22. Werner S, Grose R. Regulation of wound healing by growth factors and cytokines. Physiol Rev 2003;83:835-70.

23. Seeger MA, Paller AS. The roles of growth factors in keratinocyte migration. Adv Wound Care 2015;4:213-24.

24. Safferling K, Sutterlin T, Westphal K, Ernst C, Breuhahn K, James M, et al. Wound healing revised: A novel reepithelialisation mechanism revealed by in vitro and in silico models. J Cell Biol 2013;203:691-709.

25. Gabbiani G, Gabbiani F, Heimark RL, Schwartz SM. Organization of actin cytoskeleton during early endothelial regeneration in vitro. J Cell Sci 1984;66:39-50

26. Mekala S, Kumar NM, Das L, Shetty N, Amuthan A, Vulli V, et al. Evaluation of wound healing activity of ethanolic extract of Lanata camara in streptozotocin induced diabetic rats. Int J Pharam Pharm Sci 2014;6:631-326-3.

27. Thakur R, Jain N, Pathak R, Sandhu SS. Practices in wound healing studies of plants. Evid Based Complement Altern Med 2011;2011:438056.

28. Kim HJ, Xu L, Chang KC, Shin SC, Chung JI, Kang D, et al. Anti- inflammatory effects of anthocyanins from black soybean seed coat on the keratinocytes and ischemia-reperfusion injury in rat skin flaps. Microsurgery 2012;32:563-70.

29. Park K, Lee JH, Cho HC, Cho SY, Cho JW. Down-regulation of IL6, IL8, TNF-alpha and IL1 beta by glucosamine in HaCaT cells, but not in the presence of TNF-alpha. Oncol Lett 2010;1:289-92.

30. Park YM, Noh SU, Kim HS, Kang H, Lee JY, Kim HO. Epigallocatechin3-gallate has an anti-inflammatory effect by regulating macrophage migration inhibitory factor-induced t- helper related chemokines and cytokines in human HaCaT cells. Clin Immunol 2010;135:S124-5.

31. Reynolds T, Dweck AC. Aloe vera leaf gel: A review update. J Ethnopharmacol 1999;68:3-37.

32. Chithra P, Sajithalal GB, Ghandrakasan G. Influence Aloe vera, on collagen turnover in healing of dermal wounds in rats. Indian J Exp Biol 1998;36:896-901.

33. Chithra P, Sajithalal GB, Ghandrakasan G. Influence Aloe vera, on collagen turnover in healing of dermal wounds in rats. Influence Mol Cell Biochem 1998;181:71-6.

34. Davis RH, Leitner MG, Russo JM, Byrne ME. Wound healing. Oral and topical activity of Aloe vera. J Am Podiatr Med Assoc 1989;79:559-62. 